\title{
A coral-rubble ridge as evidence for hurricane overwash, Anegada (British Virgin Islands)
}

\author{
M. Spiske ${ }^{1}$ and R. B. Halley ${ }^{* * * *}$ \\ ${ }^{1}$ Westfälische Wilhelms-Universität, Institut für Geologie und Paläontologie, Corrensstrasse 24, 48149 Münster, Germany \\ * formerly at: USGS, 600 4th St South, St. Petersburg, FL 33701, USA \\ *** retired \\ Correspondence to: M. Spiske (spiske@uni-muenster.de)
}

Received: 31 July 2013 - Revised: 13 November 2013 - Accepted: 15 November 2013 - Published: 28 January 2014

\begin{abstract}
A coral-rubble ridge fringes part of the north shore of Anegada, a low-lying island in the northern Caribbean. Both historical reports and the geological record underline its vulnerability to tsunami and hurricanes. In this study we document the sedimentary characteristics of a coral-rubble ridge, which extends discontinuously along $1.5-1.8 \mathrm{~km}$ of chiefly north-facing shores at Soldier Wash. The ridge is less distinctive and appears only in patches along the west-facing shoreline at Windless Bight, where the wave regime is calmer. It is located ca. $8 \mathrm{~m}$ from the fair-weather shore, has a maximum width of $15 \mathrm{~m}$ and a maximum thickness of $0.8 \mathrm{~m}$. The lower seaward-facing slope of the ridge is relatively flat, probably due to successive reworking, whereas the upper seaward slope is steep and partly displays avalanching faces. The landward flank is gently sloping and terminates abruptly. The ridge is mainly composed of well-rounded, encrusted and bored coral rubble (average diameter of $16 \mathrm{~cm}$ ) that has been reworked in the shallow marine environment prior to transport. Only a few pieces of angular beach rock and karstified Pleistocene limestone are incorporated. The components build a clast-supported framework. No sand is present in the interstices. Imbrication of flat clasts indicates a deposition during landward bed load transport. The ridge morphology, composition and related hydrodynamic conditions during its emplacement are typical for coral-rubble ridges deposited by hurricane-induced storm surges. In comparison, nearby evidence for tsunami inundation is very different because the tsunami-transported coral boulders on Anegada are much bigger $(2 \mathrm{~m})$ than the biggest components in the ridge, they are deposited much farther inland (up to $1.5 \mathrm{~km}$ ), and the corals seem to have been freshly broken out of the reef by the tsunami.
\end{abstract}

The age of the ridge is difficult to estimate. The dark grey surface of the ridge is caused by bioweathering by endolithic organisms that takes tens of years and may give a very rough estimate of the minimum age of the ridge.

Storms and related surges that built the ridge were likely stronger than 2010 hurricane Earl, which attained category 4 north of the island. Earl was able to slightly rework the lower seaward part of the ridge, but transported only few and smaller pieces of coral rubble and sand onshore. Therefore, the coral-rubble ridge found at the north shore of Anegada may imply that the island is vulnerable to hurricane-induced surges of greater impact (in relation to storm path and intensity) compared with the any of the recently documented storms which were only able to rework the ridge.

\section{Introduction}

Coastal rubble or sand ridges are archives of coastal processes, either long-term processes or short-term events, as well as gradually changing parameters, like varying sediment supply, wave regime, and sea level fluctuations (e.g., Anthony, 1995; Tanner, 1995; Taylor and Stone, 1996; Otvos, 2000; Harvey, 2006; Scheffers et al., 2011; Tamura, 2012). Depending on the coastal setting, ridges may exhibit evidence for coastal progradation (e.g., Taylor and Stone, 1996; Otvos, 2000; Tamura, 2012), may be linked to historical or recent storms (e.g., Nott, 2004; Spiske and Jaffe, 2009; Forsyth et al., 2010; May et al., 2013), and can indirectly be connected to climate phenomena, such as El Niño events (e.g., Ortlieb et al., 1992; Wells, 1996). In case of a stormsurge origin the height of the ridge crest above sea level 
can act as a guide to minimum water levels during inundation (e.g., Scheffers et al., 2011; Tamura, 2012). Coastal ridges are commonly formed above high tide level landward of beaches or on top of coastal platforms and are aligned roughly parallel to the coastline. Ridges can be single features or present as multiple ridge sequences at different distances from the coast.

Coastal ridges can either be composed of sand or coarse clasts (e.g., reef rubble). This contribution focusses on the latter. Coral-rubble ridges are documented at several locations worldwide, amongst others from Australia (e.g., Scheffers et al., 2012), Pacific atolls (McKee, 1959; Maragos et al., 1973; Baines et al., 1974; Baines and McLean, 1976), Hawaii (e.g., Richmond et al., 2011), and the Caribbean (e.g., Morton et al., 2006, 2008; Richmond and Morton, 2007; Spiske and Jaffe, 2009; Caron, 2011). For most of these examples a tropical-storm origin is well documented and post-event surveys following a storm event reported coral-rubble ridge emplacement by storm waves. Moreover, none of the numerous post-tsunami surveys conducted during the last decade reported the deposition of similar, spatially confined ridges (e.g., Scoffin, 1993; Morton et al., 2008; Etienne et al., 2011; Goto et al., 2012). Considering the different hydrodynamic processes associated with storm and tsunami inundation a tsunamigenic emplacement of coarse-clast ridges is unlikely (e.g., Sugawara et al., 2008; Weiss, 2012). Hence, combining field evidence for recent storms and the related hydrodynamic aspects, coral-rubble ridges are most probably the result of storm wave action (e.g., Baines and McLean, 1976; Morton et al., 2006, 2008; Spiske and Jaffe, 2009).

In this study we survey the sedimentology and morphology of a coral-rubble ridge (Figs. 2, 3, 4, 5) that discontinuously stretches over a distance of $1.5-1.8 \mathrm{~km}$ along the northern shore of Anegada (British Virgin Islands). This documentation is of significance in the light of ongoing studies that aim to reconstruct the coastal hazard and inundation event history of Anegada (Atwater et al., 2012a, b, 2013, 2014; Buckley et al., 2012; Watt et al., 2012; Wei et al., 2012; Weil Accardo et al., 2012). The results of this study can be used for the local calibration of possible magnitudes of historical events that impacted the island. This study also contributes to the ongoing discussion on storm versus tsunami emplacement of coarse grained coastal sediments.

\section{Setting}

\subsection{Anegada}

Anegada is the northernmost island of the archipelago of the British Virgin Islands (Fig. 1a) and situated about $125 \mathrm{~km}$ south of the Puerto Rico trench which marks the seaward edge of the Caribbean plate. In contrast to the other islands within the northern Caribbean, Anegada does not have a magmatic basement or steep topography, but is a flat Pleis-

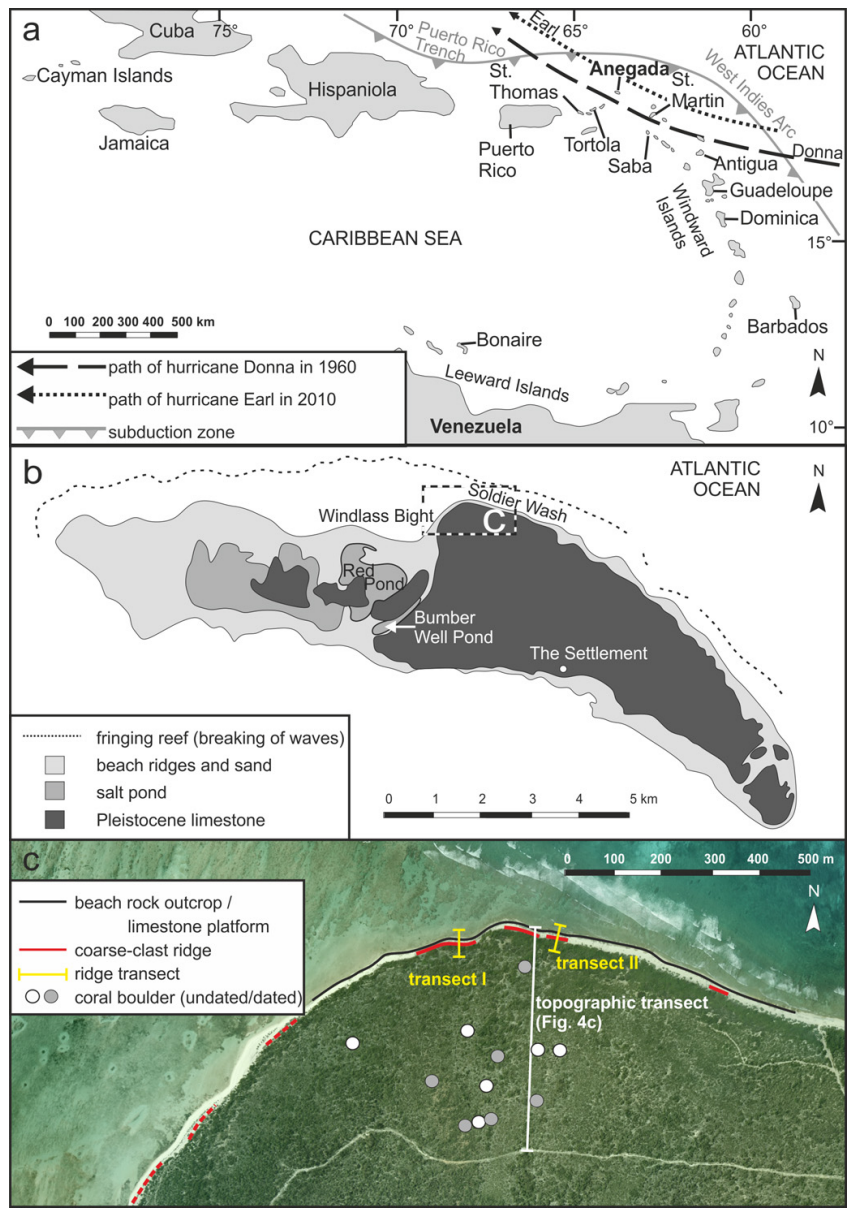

Fig. 1. (a) Map of the Caribbean Sea. (b) Generalized geologic map of Anegada. (c) Detailed view of the central north shore indicating the location of the coral-rubble ridge, the surveyed transects, sites of (tsunamigenic?) coral boulders and the location of the topographic profile in Fig. 4c (Weil Accardo et al., 2012).

tocene carbonate platform (Howard, 1970). The highest elevation, close to The Settlement is about $8 \mathrm{~m}$ above sea level (ma.s.1.) (Fig. 1b). The coast consists of sandy beaches with several generations of sandy beach ridges in their back. Hypersaline ponds in which microbial mats are growing, dominate the western part of the island, whereas the eastern part is mainly represented by karstified Pleistocene limestone pavements (Howard, 1970; Fig. 1b).

Easterly winds are year-round prevailing on Anegada (IRF, 2013; Meteo365, 2013). The mean direction of the ocean swell approaching Soldier Wash is NNE to NE because of wave refraction and wave heights are commonly not exceeding $2 \mathrm{~m}$ (Fig. 1c; IRF, 2013; Meteo365, 2013). A fringing reef grows on Anegada's northern and northeastern side (Fig. 1b). It protects the lagoon at Windlass Bight because larger waves will break $0.1-1.5 \mathrm{~km}$ off the coast. Consequently, the sandy subtidal flat and a shallow lagoon (max. water depth is $2 \mathrm{~m}$ at low tide) between the reef and the north coast exhibits 
calm wave conditions (Dunne and Brown, 1979). Dunne and Brown (1979) report that the reef and subtidal flat host abundant marine life. Unfortunately, recently this diversity decreased (Gardner et al., 2003; Miller et al., 2009; IRF, 2013). The nearshore environments produce sufficient carbonate sediment to provide calcareous material for transport to the shore during high-energy wave events, such as a hurricane or tsunami.

\subsection{Hurricane history of Anegada}

The most recent hurricane that affected Anegada was hurricane Earl in August 2010 (Atwater et al., 2014). Earl passed Anegada on 30 August 2010 as a category 4 hurricane (wind speed $115 \mathrm{knots}$ ), only $30 \mathrm{~km}$ to its north (Cangialosi, 2011; Fig. 1a). The associated storm waves deposited wrack lines along Anegada's coast and in the salt ponds (Atwater et al., 2014). Swash lines reached elevations of $2 \mathrm{~m}$ a.s.l. at Windlass Bight, and $1.5 \mathrm{~m}$ near The Settlement on the southern coast. The most widespread feature left by Earl were remains of microbial mats that were stirred up by wind-induced waves in the salt ponds and deposited along the shore of these ponds (Atwater et al., 2014). A mixture of sand and mud was deposited on top of pre-existing spillover fan along the southern shoreline. This maximum $10 \mathrm{~cm}$ thick sand layer reached several tens of meter inland (Atwater et al., 2014). Even though storm wave heights were greatest on the north shore, no distinctive storm features except the wrack lines were documented there.

Another hurricane that affected Anegada in the last decades was hurricane Donna in 1960. Even though it was only a category 3 , Donna was the hurricane with the severest effects (National Oceanic and Atmospheric Administration, 2012) because its eye passed only $15 \mathrm{~km}$ south of Anegada (Dunn, 1961; Fig. 1a). Donna caused a ca. $2.5 \mathrm{~m}$ high surge south of the The Settlement (Atwater et al., 2012b).

Other significant hurricanes were Hugo in 1989 (120 km south of Anegada), Luis in 1995 (80 km north) and Omar in 2008 (80 km east). Historical hurricanes happened in 1713, when the neighboring island Tortola was severely damaged (Pickering, 1983), and in 1819 (Schomburgk, 1832).

\subsection{Tsunami hazard}

Aside from hurricanes and tropical storms, Anegada is also vulnerable to tsunami. These tsunami can be caused by regional triggers, such as earthquakes or submarine slides in the Puerto Rico trench, or be trans-Atlantic tsunami, such as the one caused by the 1755 Lisbon earthquake. A list of Caribbean tsunami events affecting neighboring islands (e.g., in $1690,1785,1787,1761$ ) is given by McCann et al. (unpublished). However, the plausibility of these regional events is doubtful. If these events may have affected Anegada, sparse and discontinuous settlement of people on Anegada hampered their documentation. The 1755 Lisbon tsunami af- fected the neighboring islands Hispaniola, Cuba, St. Martin, Saba, Antigua, Guadeloupe and Dominica but has not been registered on Anegada (Barkan et al., 2009). Recent modeling attempts (Buckley et al., 2012; Wei et al., 2012) that are based on these observations on the neighboring islands show that the 1755 tsunami may have had a moderate impact on Anegada. Further modeling also demonstrated that locally generated tsunamis (e.g. in the Puerto Rico trench or on the outer rise) will even have a more severe effect along Anegada's coasts.

Sedimentological evidence which may be related to tsunami inundation has recently been reported from Anegada (Atwater et al., 2012a, b, 2013, 2014; Buckley et al., 2012; Watt et al., 2012; Wei et al., 2012; Weil Accardo et al., 2012). Depositional features include (graded) sediment units found within the salt ponds. These units contain articulated marine shells, beach sand and are capped by a mud layer. Scattered coral boulders (ca. $2 \mathrm{~m}$ in diameter) are found up to $1.5 \mathrm{~km}$ inland and may represent a second even more energetic inundation event, as underlined by recently obtained ages (Atwater et al., 2012a, 2013; Weil Accardo et al., 2012). Sand ridges on the northwestern shore exhibit erosional signs of breaching in heights of 2-3 m above current sea level (Atwater et al., 2012b). Radiocarbon ages obtained from coral boulders, articulated shells and leaves span a first time interval from 1650-1800 AD and a second from 1200-1450 AD pointing to at least two severe inundation events that hit Anegada. A temporal correlation of sediments and breaches is still in progress (Atwater et al., 2013).

\section{Methods}

We surveyed the coral-rubble ridge along two transects (Figs. 1c and 2). Each transect started at mean tide level and ended at the most landward point of the ridge. Straight transect lines were lain out using a $50 \mathrm{~m}$ long tape. For every surface clast along the survey line the dimensions (average length, width and height), the type of clast (rock type, coral species) was determined, and the degree of angularity, roundness, karstification, encrustation and borings was documented (Appendices A1 and A2).

Along transect II a trench was hand-dug perpendicular to the alignment of the ridge, i.e. perpendicular to the coast (Figs. 2 and 3). This trench was used to document sedimentary structures, such as imbrication or the presence of possible grain size trends (e.g., grading or landward fining).

Topographical profiles were measured with a differential GPS system in 2009 and 2012. Corrections were made using data of a fixed reference station in Charlotte Amalie (St. Thomas), however the data may comprise a vertical error of a few tens of centimeters relative to heights obtained in 2009 (see Atwater et al., 2012b; Buckley et al., 2012). This is because of problems in referencing 2012-data to a local tide gauge, the choice of the ellipsoids, and a steep gradient in the 

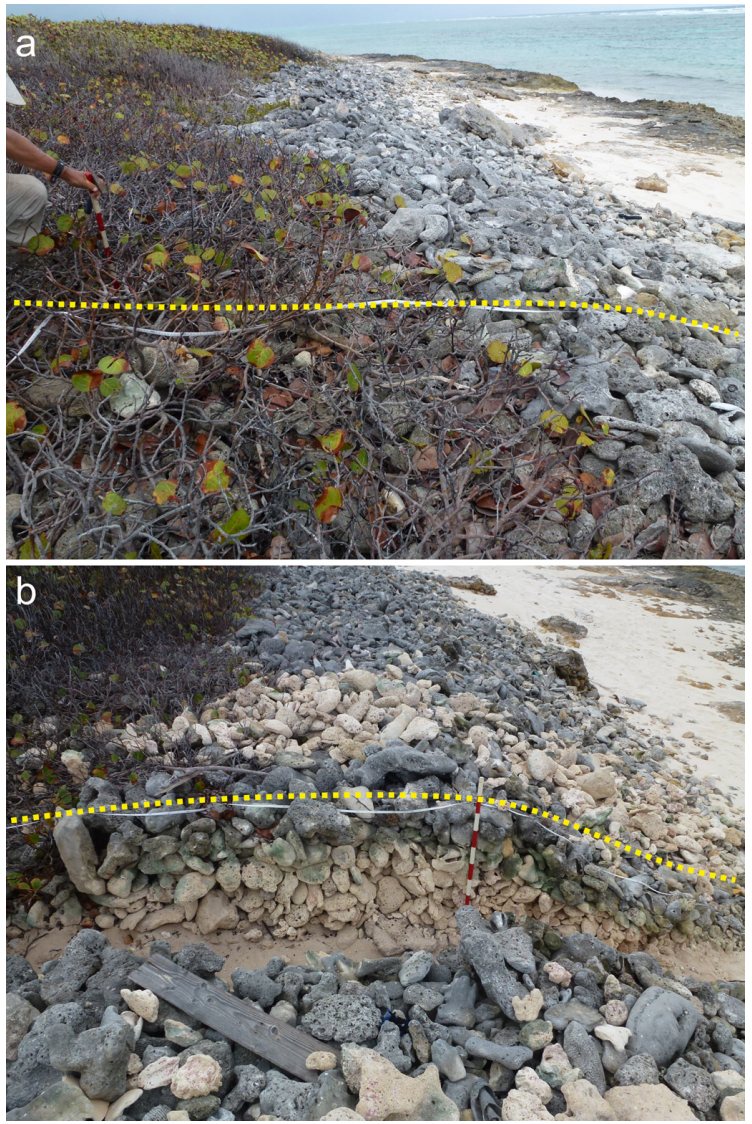

Fig. 2. Typical ridge deposits on Anegada. (a) Ridge transect I, and (b) transect II, both resting on top of a $0.5-1.3 \mathrm{~m}$ high limestone platform (yellow line marks survey line).

geoid near the Puerto Rico trench. The error only applies for comparisons to data from 2009; data assembled at all sites surveyed in 2012 is congruent relative to each other. Preliminary data is assembled in the schematic topographic profiles in Fig. 4. Additionally, in transect II, after digging the trench, the elevation of the ground surface on which the ridge is resting, was leveled with the differential GPS to gain detailed information on the ridge thickness (Fig. 4). The thickness of the ridge was additionally measured with a tape measure.

\section{Results}

The coral-rubble ridge is a discontinuous feature that can be followed over a distance of about $1.5-1.8 \mathrm{~km}$ along the northern shore (Fig. 1c). It runs parallel to the coast, which bends from a WNW-orientation at its western end at Windlass Bight to a northward to NNE-orientation at its easternmost part at Soldier Wash. At Soldier Wash the reef is located only $0.1 \mathrm{~km}$ off the coast, whereas the distance between reef and coast increases to ca. $0.9 \mathrm{~km}$ at Windlass Bight where the ridge ends. At both transect locations the ridge is sitting on top of a limestone platform which is partly covered by sand on the ridge's seaward side; the platform height at the seaward edge is 0.4-
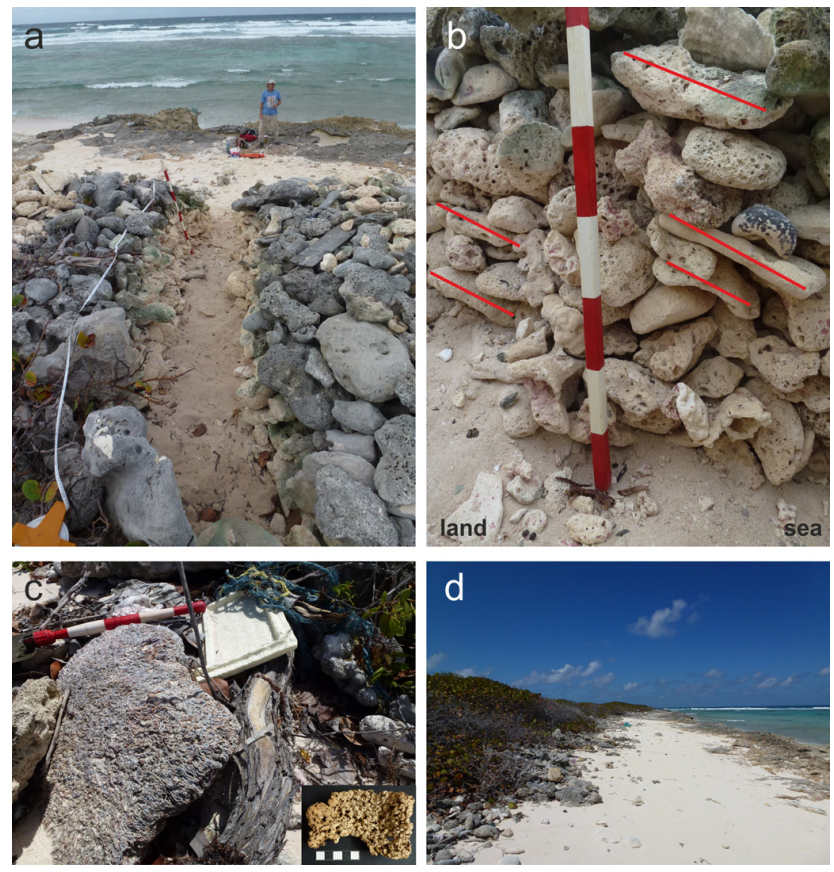

Fig. 3. Detailed views of the trench at transect II. (a) View through trench towards sea. Note the dark grey surface of weathered clasts in the upper part. (b) Details of the lower and middle part of the ridge. The ridge is resting on top of coarse grained sand, but no sand is present in between the clasts. Some flattened clasts display a landward imbrication (indicated by red lines). (c) Ropes, styrofoam and pieces of plastic trapped under a serpulite rock boulder. The inset shows a piece of cork that was trapped ca. $40 \mathrm{~cm}$ deep in the trench. (d) Incompletely developed coral-rubble accumulations.

$0.5 \mathrm{~m}$ in transect $\mathrm{I}$ and $1.3 \mathrm{~m}$ a transect II. The ridge nestles to the platform which rises to 3-4 ma.s.l. in a distance of roughly $20 \mathrm{~m}$ from the shore.

As a function of the spatially changing topography (e.g., presence or absence of beach rock platforms), a typical ridge morphology with a moderately inclined lower seaward slope and a steeper upper seaward slope, a crest and a more gently sloping landward side (e.g., Baines et al., 1974; Morton et al., 2006, 2008; Spiske and Jaffe, 2009) has only partly developed (Fig. 4a, b). We surveyed two transects perpendicular to the ridge's longitudinal axes, (i.e. perpendicular to the coastline) at places where such a typical ridge morphology was best developed (Figs. 1c, 2). At one location the ridge has a very steep seaward slope that seems to have collapsed (Fig. 5a). In transect I (Appendix A1) the ridge starts $8.2 \mathrm{~m}$ from the mean tide level. It ends $19 \mathrm{~m}$ from the shore and has a width of $10.8 \mathrm{~m}$ (Fig. 2a). Its crest reaches a maximum elevation of about 3 ma.s.l. The ridge at transect II (Appendix A2) starts at $8.6 \mathrm{~m}$ and extends $23.5 \mathrm{~m}$ from the shore. Its width is $14.9 \mathrm{~m}$ and the maximum elevation is about 3 ma.s.l. (Fig. 2b). The greatest ridge thickness of $0.8 \mathrm{~m}$ occurs at its crest (Fig. 4a). At all locations the ridge terminates abruptly in landward direction. Only few solitary limestone 
clasts are strewn farther landward and are caught in the vegetation without showing a distinctive depositional pattern. No sandy material is present on the landward side of the ridge.

In general, the main components of the ridge in both transects are: beach rock, Pleistocene limestone, reef rock, conch shells (Strombus gigas), serpulite rock (consisting entirely of calcareous of worm tubes), and the corals Acropora, A. cernivoris, A. palmata, Diploria, D. labyrinthiformis, Montastrea, M. cavernosa and Porites. Minor components are coralline algae and the corals Favosites and Milleporida. The calcareous components have grey bioweathered surfaces that create the dark grey appearance of the ridge surface (Figs. 2, 3).

At transect I the ridge constitutes $42 \%$ corals, $16 \%$ Pleistocene limestone, $8 \%$ beach rock, $3 \%$ serpulite rock, $2 \%$ reef rock, and $2 \%$ conch shells (Appendix A1; Fig. 5b). Only $3 \%$ of the clasts (mainly beach rock slabs) have freshly broken surfaces. $85 \%$ of the clasts are rounded and $12 \%$ are moderately to strongly karstified. $65 \%$ of the clasts have $\mathrm{Ho}$ motrema rubrum (Lamarck) encrustations on their surfaces and $85 \%$ of the clasts show signs of borings by marine organisms.

The ridge in transect II is composed of $61 \%$ corals, $28 \%$ reef rock, $5 \%$ conch shells, $4 \%$ serpulite rock, $1 \%$ beach rock, and $1 \%$ Pleistocene limestone (Appendix A2; Fig. 5c). None of the clasts show signs of recent breakage from the reef or beach rock exposures. $92 \%$ of the clasts are rounded and $8 \%$ are moderately to strongly karstified. $80 \%$ of the clasts show Homotrema rubrum (Lamarck) encrustations and $96 \%$ of the clasts have borings.

In comparison (Fig. 5b, c), transect I contains more beach rock, Pleistocene limestone, and corals compared with transect II. In turn, transect II contains more serpulite rock, conch shells and reef rock compared with transect I. Acropora dominates in both transects, followed by Diploria and Montastrea. All other corals represent just a minor portion of the total composition.

The seaward upper parts of the ridge contain ropes, cork, seaweed, drift wood, plastic, and pieces of styrofoam that have been washed onshore (sub)recently (Fig. 3c). Additionally, some small to medium sized clasts have recently been moved upside down, evidenced by the white, unweathered surfaces at the top compared with grey weathered surfaces at the bottom or side (Figs. 2b, 3a).

The trench that cuts through the ridge at transect II does not show any internal vertical grain size trends. Horizontal trends are visible in Fig. 2a and b where small boulders are resting on the seaward side of the ridge. Parts of the ridge depict imbrication of flat components (Fig. 3b). The landward directed imbrication has angles of $24-30^{\circ}$. The ridge fabric is clast-supported with an average clast size of about $16 \times 11 \times 4 \mathrm{~cm}$ (Appendices A1 and A2). No sand is present in the interstices between the clasts and the ridge contains only a few big marine shells (about $5-8 \mathrm{~cm}$ in diameter). Very little sand is present in the lowermost ca. $5 \mathrm{~cm}$ of the ridge.

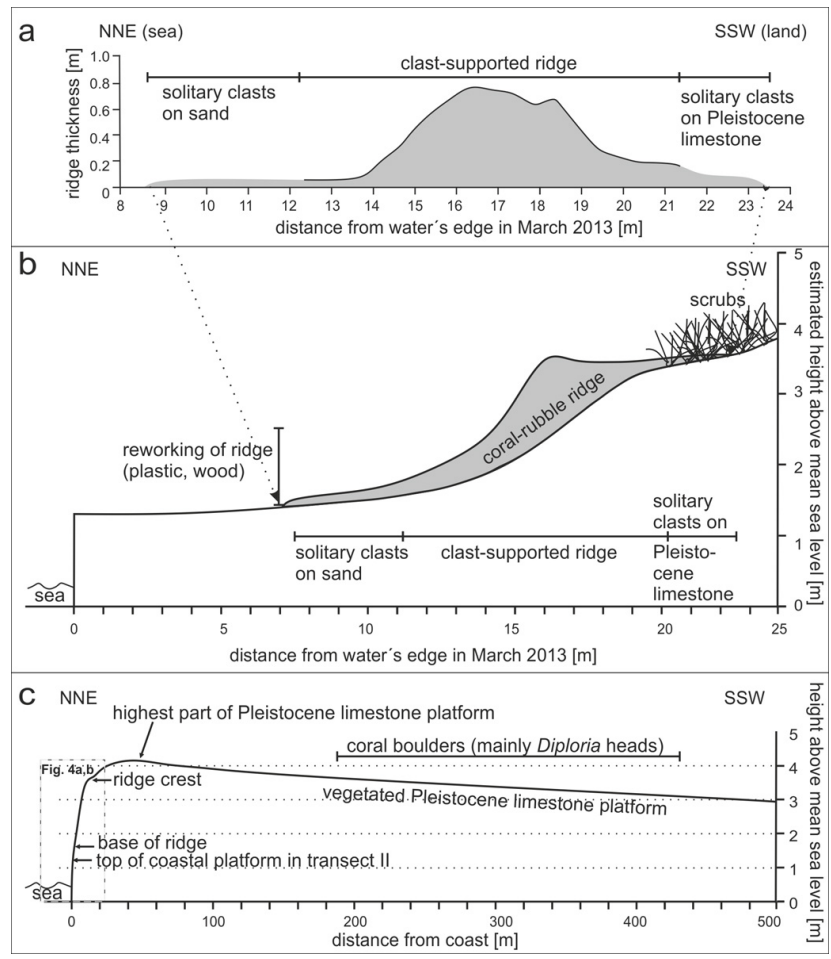

Fig. 4. (a) Schematic cross section of transect II depicting thickness and morphology of the ridge without underlying topography. Note that the ridge lies on top of a ca. $1.3 \mathrm{~m}$ high limestone platform. (b) Schematic topographic profile showing the onlap of the coralrubble ridge onto the Pleistocene platform. (c) Topographic cross section reaching from the shore onto the limestone platform. Coral boulders are strewn on top of the platform between about 200$450 \mathrm{~m}$ from the shore (after: Weil Accardo et al., 2012; Fig. 1c).

\section{Discussion}

\subsection{Sediment entrainment and ridge deposition}

The appearance of the ridge on Anegada is completely different from other coarse-clast deposits, like huge coral boulders (Fig. 5d, e) that were most probably transported on land by a tsunami (Atwater et al., 2012a, b, 2013, 2014; Buckley et al., 2012; Watt et al., 2012; Wei et al., 2012; Weil Accardo et al., 2012). The boulders can be found as far as $1.5 \mathrm{~km}$ inland, are in many cases isolated and do not show a linear aligned accumulation. Additionally, the coral boulders do not exhibit any signs of abrasion prior to transport and have therefore been freshly broken out of the reef by the tsunami. Their size (max. $2 \mathrm{~m}$ ) is much larger than the largest components within the ridge (max. $0.75 \mathrm{~m}$ ).

\subsubsection{Implications given by morphology and clast organization}

The capacity of storms to form coarse-clast ridges is an important criterion that allows the distinction from tsunami 

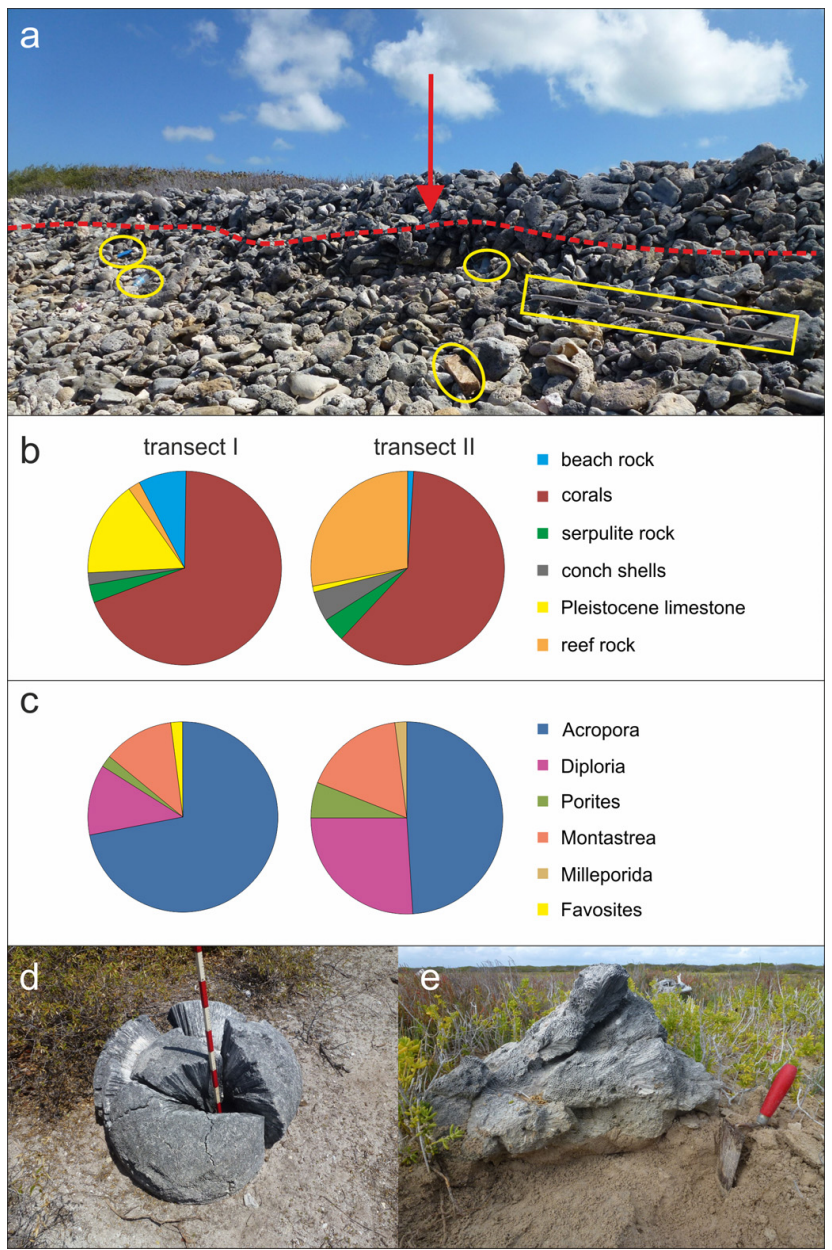

Fig. 5. (a) Evidence for ridge reworking on its seaward side. A steep scarp (red arrow) seems to have collapsed. Recent rubbish (yellow: plastic bottles, flip flops, drift wood) was deposited seaward of the proposed limit of reworking (red dashed line). (b) Percentage of each component, and (c) percentage of each coral species in transects I and II. Typical tsunami-transported coral boulders of (d) Diploria and (e) Montastrea that have been freshly broken off the reef during the respective event.

emplaced coarse-clast deposits (e.g., Etienne and Paris, 2010; Paris et al., 2011). This is because the organization (e.g., imbrication) of such a ridge requires multiple reworking by waves rather than the impact of a single tsunami wave front (e.g., Williams and Hall, 2004; Etienne and Paris, 2010). The coral-rubble ridge on the central northern shore of Anegada comprises several characteristics typical for such presumably storm emplaced ridges, such as a clast-supported fabric with hardly any sandy material in between, a dominant fraction of well-rounded and incrusted reef-rubble clasts, imbrication of flat clasts, and an abrupt landward termination (e.g., McKee, 1959; Baines et al., 1974; Morton et al., 2006, 2008; Richmond and Morton, 2007; Spiske and Jaffe, 2009).

The ridge is mainly composed of cobble-sized rounded clasts, constituting a clast-supported fabric with clasts being wedged between other clasts (Figs. 2, 3, 5b, c). As Fig. 2d depicts, there is no sand infilling the interstices. Only a negligible portion of coarse carbonate sand is present at the bottom. This observation is similar to hurricane ridges documented on Pacific atolls and in the southern Caribbean Sea (McKee, 1959; Maragos et al., 1973; Spiske and Jaffe, 2009). The most conclusive interpretation is that most of the sand was transferred back into the sea by wave action during the storm or the retreating storm surge (e.g., Lorang, 2000), whereas the seaward flow was not able to move the already trapped cobbles and a few trapped bigger shells. The remaining sand then percolated though the interstices of the coarse clasts and accumulated in the lower part of the ridge.

The ridge on Anegada does not exhibit a lobate landward end and it is not sheet-like. Several ridge-like storm deposits, both in sandy and coarse-clastic settings, exhibit such lobate (tongue-shaped) landward termination (e.g., Blumenstock et al., 1961; Scoffin, 1993; Goff et al., 2004; Morton et al., 2006, 2008; Claudino-Sales et al., 2008; Spiske and Jaffe, 2009). Most probably a lobate landward end did not develop on Anegada because the dense, scrubby vegetation in the back of the beaches hampered an undisturbed development of the landward edge (Fig. 4b). Instead, the vegetation decreased the flow speed of the storm waves and thus favored an abrupt landward termination with only a few solitary clasts strewn in between the bushes. Further on, the narrow beaches (not more than $4-8 \mathrm{~m}$ wide at places where the ridge developed) and relatively steep topography (rising from sea-level up to ca. 4 ma.s.1.; Fig. 4c) in the back of the beaches, hampered the development of a sheet-like geometry because the wave energy was not able to decrease uniformly.

\subsubsection{Implications given by internal sedimentary structures and related hydrodynamics}

Imbrication of flattened or elongated clasts develops parallel to unidirectional flowing water (Harms et al., 1975; Johansson, 1976). The alignment of the clasts that constitute the ridge on Anegada, thus gives evidence for an emplacement by landward flowing water. The imbrication angle can be used to refer to a relative flow speed of the water and the amount of clasts being transported in the fluid, i.e. the higher the angle of imbrication, the larger the aggradation rate, the faster and denser packed is the fluid, and the bigger the transported components (Johansson, 1976). Since the angle of imbrication does not significantly change within the ridge on Anegada, no statement can be made on relative changes in flow parameters during its deposition. But, because imbrication indicates bed-load transport is dominant (Harms et al., 1975; Johansson, 1976), we can state that this has been the prevailing mode of clast transport. Imbrication of flattened clasts in hurricane ridges was also observed by McKee (1959), Baines et al. (1974) and Spiske and Jaffe (2009). Bluck (1967) argues that imbrication is the result of multiple wave run up, and that such conditions typically prevail 
during storm surges during which thousands of waves wash ashore (e.g., Williams and Hall, 2004; Etienne and Paris, 2010; Weiss, 2012). These conditions do not occur during tsunami inundation.

Spiske and Jaffe (2009) were able to show that under certain conditions coarse-clast ridges can preserve evidence for flow directions and relative flow energies during the major phases of a storm surge, such as the setup, peak and retreat of the surge. At Anegada, no distinction of different units can be made. Internal structures do not change in the vertical or horizontal directions and the angles of imbrication remain constant throughout the ridge. Therefore, we conclude that the ridge was deposited by landward flowing water, most probably during the setup and peak of a hurricane-related storm surge.

\subsubsection{Implications given by clast characteristics and origin}

The lack of grain size trends may be explained by the fact that the storm waves were only able to transport clasts of a limited size and that the source of loose clasts, especially in the shallow marine water, provided only a very restricted clast size spectrum. Additionally, the waves were not able to rip off new material from the living reef. Larger cobbles or boulders in or close to the seaward basal part of the ridge (Fig. 2a, b) may have been too large to be transported further up-beach by the storm waves (e.g., Oak, 1984). These boulders are larger than the material in the ridge and may be relicts of a previous event of higher wave energy, such as a tsunami (e.g., Morton et al., 2008; Spiske et al., 2008). Such a tsunami event that predates a major historical storm on Anegada may also have provided a large quantity of loose clasts onshore and in shallow marine settings which were subsequently available for storm remobilization or reorganization. Such a scenario was observed by Paris et al. (2010) after the 2004 Indian Ocean tsunami that provided clasts that were later remobilized and redeposited as a cobble-to-pebble ridge by a storm. In the latter example, the development of a ridge may not have been possible without a prior tsunami event because of the lack of available coarse clastic material. This may also apply for Anegada, where the ridge may inherit an unknown quantity of previously tsunami entrained clasts which then were reused to build a post-tsunami storm ridge deposit.

The shape and surface condition of the clasts give information on the source area of clast entrainment by the storm waves. Most of the clasts were already well-rounded prior to transport, indicating a longer retention period in the shallow marine foreshore environment where broken coral fragments were constantly moved by normal waves and successively rounded. This is underlined by the large number of clasts being encrusted by Homotrema rubrum which colonizes shallow marine coral rubble within the reef or on the reef flat (MacKenzie et al., 1965; Pilarczyk and Reinhardt,
2012; Reinhardt et al., 2012). Additionally, holes produced by boring organisms cover many of the clasts and also indicate the extended retention time of the clasts in shallow marine waters before transport. Only very few components have angular surfaces that suggest that they were freshly broken from the reef by the storm waves and then transported onshore. A minor portion of karstified clasts indicates a subaerial exposure within the swash zone or zone of sea spray prior to transport. Consequently, the components that constitute the coral-rubble ridge on Anegada derive from three environments, namely the shallow marine foreshore, the reef and subaerial beach rock and limestone exposures adjacent to the shore. The latter two settings are only sparsely represented.

\subsubsection{Implications given by ridge distribution in relation to the alignment of the coast and the local wave regime}

The ridge between Windlass Bight and Soldier Wash is unique because no similar structure can be found elsewhere on Anegada. It cannot be compared with beach ridges in the western part of the island because the latter occur as ridge sequences at varying distances from the coast, hence reflecting the progradation of the coastline. These western ridges are composed of sand, in some cases containing scattered coral fragments.

The restricted and even patchy occurrence of the coralrubble ridge over $1.5-1.8 \mathrm{~km}$ along the northern shore (Fig. 1c) may be controlled by various agents. First of all the ridge occurs where the coast is closest to the reef $(100 \mathrm{~m})$, hence transport distances of coral rubble from the reef to the shore are short and require less energy compared with other locations along the windward shore where the wave energy already decreased significantly before reaching the shore (Fig. 1b,c). In addition, the area is the northernmost point of Anegada where the alignment of the shore changes from NNE to WNW within a short distance (Fig. 1b,c). Waves approaching the coast commonly from NNE to NE are probably most energetic at this site. The wind drag forces the water to flow into the embayment of Windless Bight where the wave energy then rapidly drops. This effect may similarly act in the case of storm waves. Finally, the area where the ridge is present is the only part of the shore where Pleistocene limestone crops out and where a narrow (of 0.4$1.3 \mathrm{~m}$ high) coastal platform occurs, providing different hydrodynamic conditions for the inundation by waves compared with the sandy beaches elsewhere on Anegada. During a post-Earl survey ( 5 months after the storm) along the west-facing beach at Windless Bight (where the ridges are patchy and not well developed), a thin layer of fresh sand $(<2 \mathrm{~cm}$ thick), as well as leafs and small coral fragments (ca. $10 \times 5 \times 5 \mathrm{~cm}$ ) were deposited in a swash line about 1.2 ma.s.1. (M. Tuttle, personal communication, 2013). The few coral pieces showed signs of boring by marine organisms 
and were well-rounded. This observation might imply that the wave regime during a storm is significantly different along the WNW-facing beaches close to Windlass Bight, compared with the NNE-aligned beaches near Soldier Wash where Earl possibly had higher energy and was reported to have reworked the lower parts of the ridge to heights of at least 1.5 ma.s.1. These observations add to the explanation that the alignment of the coast and the distance between the coast and the reef exert an important influence on the development of the apparently storm deposited ridge. It needs to be noted that for tsunami waves with long wave lengths compared to storms with short wave periods and lengths, the local wave regime will not have an influence on the onshore inundation parameters.

\subsection{Post-depositional reworking of the ridge}

The three-dimensional fabric of the ridge with clasts wedged between each other creates a stabile framework (e.g., Ogren and Waag, 1986; Bishop and Hughes, 1989). However, the ridge shows signs of some reworking in its lower seaward parts at Soldier Wash (Fig. 4b). Ropes, plastic and sytrofoam are incorporated in the most landward portions of the ridge (Fig. 3c), not deeper than about $20 \mathrm{~cm}$ (roughly 1-3 clast diameters). Even though this material is very light, eolian transport can be ruled out because it cannot explain how the material got trapped under clasts. The clasts that rest on top of the material are either smaller clasts of the lower part of the ridge or exceptionally light clasts (e.g. serpulite rock slab with a very low density; see Spiske et al., 2008), hence easy to be moved by less energetic storm waves during smaller storms compared with the waves being responsible for the development of the ridge itself. These smaller storm waves can also be capable of washing the remaining sand out of the ridge and back into the sea (e.g., Lorang, 2000; Morton et al., 2008). This was observed at Windlass Bight where Earl eroded beach sand surrounding a coral head down to $8 \mathrm{~cm}$, as indicated by the white unweathered lower part of the coral sticking out of the sand (M. Tuttle, personal communication, 2013). The eroded sand seems to have been transported back into the sea by the storm waves. At Soldier Wash relocation of smaller cobbles is indicated by the white color of exposed surfaces in contrast to dark grey sides or bottoms. The grey color is caused by the activity of endolithic organisms (bioweathering) that causes the sun-exposed surface to darken, thus providing an "upside down" criterion for clast movement that happened not longer than 10-15 yr ago (Pohl and Schneider, 2002). Since the cobbles still show a relatively fresh, bright surface, the movement probably occurred not more than 2-3 yr ago (Pohl and Schneider, 2002).

At the north-facing shore close to Soldier Wash, the ridge locally exhibits a steep seaward slope (Fig. 5a). The slope is steeper than in any other part, having the appearance of a small scarp. Just below the level of the scarp, debris (plastic bottles, flip flops) and wood can be found. We conclude that parts of the ridge collapsed during a smaller storm event when waves were rushing up the seaward flank, reworking the ridge (Scoffin, 1993). This storm also transported light, floating debris and wood to the lower part of the ridge. We cannot prove this, but it may be possible that this happened during hurricane Earl in August 2010. The reworking appears relatively young, but happened probably not as long ago as hurricane Donna in 1960 (using the "young" plastic bottles and flip flops as evidence for post-1960 reworking).

\subsection{Age range of the ridge}

The components that constitute the ridge are all weathered, reworked, encrusted and full of borings, providing no material suitable for dating. Indirect and relative information on the ridge's age may be given by the fact that we found pieces of cork trapped within the ridge and that the clasts are intensively weathered, as evident by their dark grey surface.

The cork is mentioned by Schomburgk (1832) who was the first historian to give a detailed overview of the history, topography, oceanography, biology and geology of Anegada. He notes that during his stay on Anegada in 1831, a great quantity of cork, which is not native to the Caribbean, was found along the north coast. Locals told him that for many years cork was washed onshore. Assuming that the cork that we found within the ridge (Fig. 3c) is indeed a relict of this historical cork, we may argue that the emplacement of the coral-rubble ridge took place some years prior to Schomburgk's visit or shortly after. Schomburgk himself mentions a very strong hurricane that devastated Tortola in 1819 and closed an inlet on Anegada's north shore, but it is unknown if cork was already washed ashore in 1819.

The dark grey surface of the ridge (Figs. 2, 3a) is caused by bioweathering of endolithic organisms, such as cyanobacteria and chlorophyceae (Pohl and Schneider, 2002). As discussed before, fresh surfaces can be colonized within about 10-15 yr in Alpine settings (Pohl and Schneider, 2002). Pohl and Schneider (2002) show that after 100-150 yr of exposure the coating by biofilms is almost complete in Alpine settings. In a tropical climate and close to the sea where sea spray will constantly moisture the surfaces the weathering rates are probably higher than in the Alpine setting studied by Pohl and Schneider (2002). On Anegada, the dark grey, intensively weathered surfaces of the clasts therefore may roughly imply an age of some tens of years.

Estimating a maximum age of the ridge is even more difficult. If recent modeling attempts are right, a $M_{\mathrm{w}}=9.0$ earthquake that generated the 1755 Lisbon tsunami would have been able to overtop the coral-rubble ridge along the north shore, most possibly eroding or at least significantly modifying it (Buckley et al., 2012; Wei et al., 2012). Field data by Atwater et al. (2012b) shows that sandy beach ridges close to Windlass Bight exhibit breaches in heights of 2-3 m above current sea level, assumed to be caused by an inundation event. However, the lack of age data does not yet allow 
a reliable temporal correlation of these breaches, e.g. to the $1650-1800 \mathrm{AD}$ event which is represented by graded shell hash layers and mud caps in Red Pond and Bumper Well Pond (Atwater et al., 2012a, b, 2013, 2014; Pilarczyk and Reinhardt, 2012). Because the coral-rubble ridge does not show extensive erosional features, we may refer that it has not existed prior to an extreme overwash event between 1650 and $1800 \mathrm{AD}$ and hence is not older than about $200 \mathrm{yr}$. This theory, however, is highly speculative because of the lack of material suitable for absolute dating.

Hurricanes documented to have affected Anegada (e.g., Schomburgk, 1832; Pickering, 1983; Dunn, 1961; Atwater et al., 2014) did not emplace a similar ridge. Anyhow, hurricane Earl in 2010 slightly reworked the lower seaward parts of the ridge. Therefore, the ridge was probably built during a hurricane that had a more severe impact on Anegada's northern shoreline than recent ones. Such effects may be, amongst others, caused by a greater hurricane intensity or by the alignment of the individual storm track. Alternatively, the ridge was deposited during a phase of increased clast availability (e.g. after a tsunami event; Paris et al., 2010), such as after the 1650-1800 AD event recorded on Anegada. The former interpretation is of significance because it underlines that individual hurricanes and related surges can cause a greater impacts on Anegada's coast compared to recent ones.

\section{Conclusions}

The coral-rubble ridge surveyed along the north shore of Anegada exhibits several features typical for a hurricaneemplaced ridge:

- A clast-supported framework with calcareous cobbles (average $16 \mathrm{~cm}$ in size) that are wedged between each other.

- The absence of sandy material in the interstices of the ridge.

- Imbrication of flattened components that indicates bed load transport and deposition by landward flowing waves, possibly during the onset and peak of a storm surge.

- Composition of mainly well-rounded coral rubble with encrustations and borings that prove a retention period in the shallow marine fore shore environment prior to onshore transport. In comparison with tsunami evidence on Anegada, the waves were not able to break fresh material out of the reef.

The minimum age of the ridge is most probably a few tens of years. This is constrained by the degree of bioerosion that affected the ridge surface. No recently documented hurricane on Anegada was capable of depositing a similar ridge, but minor reworking of the lower seaward side was caused by these less energetic events (e.g. Earl in 2010). Therefore, the hurricane that deposited the ridge along the north coast of Anegada had a more severe impact, and resulting devastation would have been more intense compared to recent storms. This study therefore highlights the vulnerability of Anegada to hurricanes and related storm surges.

\section{Appendix A}

Table A1. Clast parameters of ridge transect I (the star symbol * marks the crest of the ridge).

\begin{tabular}{|c|c|c|c|c|c|c|c|}
\hline $\begin{array}{r}\text { Distance } \\
\text { from } \\
\text { high } \\
\text { tide } \\
\text { line } \\
\text { [m] }\end{array}$ & $\begin{array}{l}\text { Clast } \\
\text { type }\end{array}$ & $\begin{array}{c}\text { Size } \\
a \text { axis } \\
{[\mathrm{cm}]}\end{array}$ & $\begin{array}{c}\text { Size } \\
b \text { axis } \\
{[\mathrm{cm}]}\end{array}$ & $\begin{array}{c}\text { Size } \\
c \text { axis } \\
{[\mathrm{cm}]}\end{array}$ & Shape & $\begin{array}{l}\text { Homotrema } \\
\text { rubrum } \\
\text { encrustation }\end{array}$ & $\begin{array}{l}\text { Borings } \\
\text { on } \\
\text { surface }\end{array}$ \\
\hline 8.20 & BR & 22 & 20 & 15 & rounded & $\mathrm{x}$ & $\mathrm{x}$ \\
\hline 8.40 & $\mathrm{BR}$ & 20 & 15 & 4 & rounded & $\mathrm{x}$ & $\mathrm{x}$ \\
\hline 8.80 & A & 20 & 8 & 4 & rounded & $\mathrm{x}$ & $\mathrm{x}$ \\
\hline 8.90 & D & 17 & 15 & 4 & rounded & $\mathrm{x}$ & $\mathrm{x}$ \\
\hline 8.95 & BR & 15 & 12 & 2 & rounded & $\mathrm{x}$ & $\mathrm{x}$ \\
\hline 9.05 & A & 10 & 8 & 1 & rounded & $\mathrm{x}$ & \\
\hline 9.30 & $\mathrm{P}$ & 55 & 35 & 10 & karstified & & \\
\hline 9.60 & $\mathrm{P}$ & 13 & 8 & 2 & rounded & $\mathrm{x}$ & \\
\hline 9.70 & A & 8 & 5 & 4 & rounded & $\mathrm{x}$ & $\mathrm{x}$ \\
\hline 9.75 & A & 6 & 4 & 1.5 & rounded & $\mathrm{x}$ & $\mathrm{x}$ \\
\hline 9.80 & A & 7 & 4 & 1 & rounded & & $\mathrm{x}$ \\
\hline 9.85 & A & 5 & 4 & 0.5 & rounded & & $\mathrm{x}$ \\
\hline 10.05 & A & 11 & 11 & 1 & broken on & & $\mathrm{x}$ \\
\hline 10.20 & $S$ & 45 & 20 & 20 & $\begin{array}{l}1 \text { side } \\
\text { partly } \\
\text { rounded }\end{array}$ & & $\mathrm{x}$ \\
\hline 10.45 & A & 10 & 10 & 1 & rounded & $\mathrm{x}$ & $\mathrm{x}$ \\
\hline 10.65 & A & 12 & 10 & 1 & $\begin{array}{l}\text { partly } \\
\text { rounded }\end{array}$ & & $\mathrm{x}$ \\
\hline 10.70 & A & 10 & 4 & 5 & rounded & $\mathrm{x}$ & $\mathrm{x}$ \\
\hline 10.80 & BR & 10 & 4 & 2 & rounded & & $\mathrm{x}$ \\
\hline 10.85 & $\mathrm{C}$ & 12 & 4 & 4 & & $\mathrm{x}$ & $\mathrm{x}$ \\
\hline 11.00 & A & 13 & 10 & 2 & rounded & $\mathrm{x}$ & $\mathrm{x}$ \\
\hline 11.10 & A & 13 & 5 & 1 & rounded & $\mathrm{x}$ & $\mathrm{x}$ \\
\hline 11.30 & $\mathrm{P}$ & 20 & 18 & 3 & karstified & & \\
\hline 11.40 & A & 7 & 5 & 1 & rounded & $\mathrm{x}$ & $\mathrm{x}$ \\
\hline 11.50 & BR & 15 & 10 & 5 & rounded & & $\mathrm{x}$ \\
\hline 11.70 & A & 14 & 13 & 1.5 & rounded & $\mathrm{x}$ & $\mathrm{x}$ \\
\hline 11.90 & A & 8 & 7 & 5 & rounded & $\mathrm{x}$ & $\mathrm{x}$ \\
\hline 12.00 & A? & 5 & 4 & 3 & rounded & $\mathrm{x}$ & $\mathrm{x}$ \\
\hline 12.20 & A & 20 & 11 & 5 & rounded & $\mathrm{x}$ & $\mathrm{x}$ \\
\hline 12.30 & A? & 13 & 10 & 2 & rounded & $\mathrm{x}$ & $\mathrm{x}$ \\
\hline 12.40 & A & 6 & 7 & 2 & rounded & $\mathrm{x}$ & $\mathrm{x}$ \\
\hline 12.50 & A & 17 & 11 & 1.5 & rounded & $\mathrm{x}$ & $\mathrm{x}$ \\
\hline 12.60 & $\mathrm{P}$ & 13 & 11 & 4 & rounded & & $\mathrm{x}$ \\
\hline 12.70 & A & 20 & 11 & 2 & rounded & $\mathrm{x}$ & $\mathrm{x}$ \\
\hline 12.80 & $P$ & 30 & 20 & 10 & $\begin{array}{l}1 \text { side } \\
\text { karstified }\end{array}$ & & $\mathrm{x}$ \\
\hline 13.05 & A & 32 & 15 & 4 & rounded & $\mathrm{x}$ & $\mathrm{x}$ \\
\hline 13.25 & D & 20 & 15 & 8 & rounded & $\mathrm{x}$ & $\mathrm{x}$ \\
\hline 13.40 & $\mathrm{P}$ & 12 & 9 & 7 & rounded & & $\mathrm{x}$ \\
\hline 13.55 & $\mathrm{~A}$ ? & 10 & 9 & 4 & $\begin{array}{l}\text { partly } \\
\text { karstified }\end{array}$ & $\mathrm{x}$ & $\mathrm{x}$ \\
\hline 13.60 & M & 15 & 14 & 4 & rounded & $\mathrm{x}$ & $\mathrm{x}$ \\
\hline 13.70 & A & 10 & 6 & 1.5 & rounded & & \\
\hline 13.90 & D?, A? & 9 & 9 & 2 & rounded & $\mathrm{x}$ & $\mathrm{x}$ \\
\hline$* 14.00$ & AP & 25 & 15 & $3-4$ & rounded & $\mathrm{x}$ & $\mathrm{x}$ \\
\hline 14.20 & A? & 10 & 10 & 2 & rounded & $\mathrm{x}$ & $\mathrm{x}$ \\
\hline 14.25 & AP & 25 & 18 & 3 & rounded & $\mathrm{x}$ & $\mathrm{x}$ \\
\hline 14.40 & AP & 10 & 8 & 1 & rounded & & $\mathrm{x}$ \\
\hline 14.45 & A & 10 & 6 & 1 & rounded & $\mathrm{x}$ & $\mathrm{x}$ \\
\hline 14.50 & PO & 10 & 7 & 5 & rounded & & $\mathrm{x}$ \\
\hline 14.60 & M & 12 & 9 & 5 & rounded & $\mathrm{x}$ & $\mathrm{x}$ \\
\hline 14.70 & MC & 10 & 8 & 4 & karstified & & \\
\hline 15.00 & M & 8 & 7 & 4 & rounded & $\mathrm{x}$ & $\mathrm{x}$ \\
\hline 15.30 & $\mathrm{~F}$ & 10 & 8 & 7 & rounded & $\mathrm{x}$ & $\mathrm{x}$ \\
\hline 15.70 & $\mathrm{RR}$ & 14 & 12 & 7 & disintegrates & $\mathrm{x}$ & $\mathrm{x}$ \\
\hline
\end{tabular}


Table A1. Continued.

\begin{tabular}{|c|c|c|c|c|c|c|c|}
\hline $\begin{array}{r}\text { Distance } \\
\text { from } \\
\text { high } \\
\text { tide } \\
\text { line } \\
\text { [m] }\end{array}$ & $\begin{array}{l}\text { Clast } \\
\text { type }\end{array}$ & $\begin{array}{c}\text { Size } \\
a \text { axis } \\
{[\mathrm{cm}]}\end{array}$ & $\begin{array}{c}\text { Size } \\
b \text { axis } \\
{[\mathrm{cm}]}\end{array}$ & $\begin{array}{c}\text { Size } \\
c \text { axis } \\
{[\mathrm{cm}]}\end{array}$ & Shape & $\begin{array}{l}\text { Homotrema } \\
\text { rubrum } \\
\text { encrustation }\end{array}$ & $\begin{array}{l}\text { Borings } \\
\text { on } \\
\text { surface }\end{array}$ \\
\hline 15.80 & A & 20 & 15 & 5 & rounded & & $\mathrm{x}$ \\
\hline 16.00 & A & 20 & 15 & 2 & rounded & $\mathrm{x}$ & $\mathrm{x}$ \\
\hline 16.40 & D & 20 & 15 & 6 & rounded & $\mathrm{x}$ & $\mathrm{x}$ \\
\hline 17.00 & S & 30 & 20 & 10 & rounded & $\mathrm{x}$ & $\mathrm{x}$ \\
\hline 17.60 & $\mathrm{P}$ & 13 & 12 & 5 & $\begin{array}{l}1 \text { side } \\
\text { karstified }\end{array}$ & & \\
\hline 18.00 & $\mathrm{P}$ & 15 & 12 & 8 & $\begin{array}{l}1 \text { side } \\
\text { karstified }\end{array}$ & $\mathrm{x}$ & $\mathrm{x}$ \\
\hline 18.20 & $\mathrm{P}$ & 20 & 18 & 5 & rounded & & \\
\hline 18.70 & M & 20 & 15 & 4 & rounded & & \\
\hline 19.00 & $\mathrm{P}$ & 45 & 25 & 5 & karstified & & $\mathrm{x}$ \\
\hline
\end{tabular}

$\mathrm{A}=$ Acropora $; \mathrm{AP}=$ Acropora palmata $; \mathrm{BR}=$ beach rock $\mathrm{C}=$ conch $; \mathrm{D}=$ Diploria $; \mathrm{F}=$ Favosites $; \mathrm{M}=$ Montastrea ; $\mathrm{MC}=$ Montastrea cavernosa $; \mathrm{RR}=$ reef rock $\mathrm{P}=$ Pleistocene linestone $; \mathrm{PO}=$ Porites $; \mathrm{S}=$ serpuilte rock.

Table A2. Clast parameters of ridge transect II (the star symbol * marks the crest of the ridge).

\begin{tabular}{|c|c|c|c|c|c|c|c|}
\hline $\begin{array}{r}\text { Distance } \\
\text { from } \\
\text { high } \\
\text { tide } \\
\text { line } \\
{[\mathrm{m}]}\end{array}$ & $\begin{array}{l}\text { Clast } \\
\text { type }\end{array}$ & $\begin{array}{c}\text { Size } \\
a \text { axis } \\
{[\mathrm{cm}]}\end{array}$ & $\begin{array}{c}\text { Size } \\
b \text { axis } \\
{[\mathrm{cm}]}\end{array}$ & $\begin{array}{c}\text { Size } \\
c \text { axis } \\
{[\mathrm{cm}]}\end{array}$ & Shape & $\begin{array}{l}\text { Homotrema } \\
\text { rubrum } \\
\text { encrustation }\end{array}$ & $\begin{array}{l}\text { Borings } \\
\text { on } \\
\text { surface }\end{array}$ \\
\hline 8.60 & $\mathrm{D}$ ? & 10 & 5 & 2 & rounded & $\mathrm{x}$ & $\mathrm{x}$ \\
\hline 9.00 & A & 12 & 7 & 2 & rounded & & \\
\hline 10.10 & $P$ & 8 & 6 & 3 & rounded & $\mathrm{x}$ & $\mathrm{x}$ \\
\hline 10.40 & D & 30 & 20 & 15 & rounded & $\mathrm{x}$ & $\mathrm{x}$ \\
\hline 10.90 & AP & 13 & 12 & 1.5 & rounded & $\mathrm{x}$ & $\mathrm{x}$ \\
\hline 11.60 & $\mathrm{D}$ & 30 & 20 & 15 & rounded & $\mathrm{x}$ & $\mathrm{x}$ \\
\hline 11.90 & $\mathrm{M}$ & 22 & 15 & 5 & rounded & $\mathrm{x}$ & $\mathrm{x}$ \\
\hline 12.05 & $\mathrm{RR}$ & 10 & 7 & 3 & rounded & $\mathrm{x}$ & $\mathrm{x}$ \\
\hline 12.15 & A & 10 & 8 & 4 & rounded & $\mathrm{x}$ & $\mathrm{x}$ \\
\hline 12.30 & $\mathrm{RR}$ & 15 & 13 & 3 & rounded & $\mathrm{x}$ & $\mathrm{x}$ \\
\hline 12.30 & $\mathrm{RR}$ & 15 & 13 & 3 & rounded & $\mathrm{x}$ & $\mathrm{x}$ \\
\hline 12.50 & A & 24 & 18 & 2 & rounded & $\mathrm{x}$ & $\mathrm{x}$ \\
\hline 12.60 & A & 15 & 12 & 3 & rounded & $\mathrm{x}$ & $\mathrm{x}$ \\
\hline 12.80 & MC & 10 & 8 & 2 & rounded & $\mathrm{x}$ & $\mathrm{x}$ \\
\hline 12.90 & RR & 13 & 10 & 3 & rounded & $\mathrm{x}$ & $\mathrm{x}$ \\
\hline 13.00 & A & 15 & 8 & 3 & rounded & & \\
\hline 13.30 & M & 15 & 9 & 4 & rounded & $\mathrm{x}$ & $\mathrm{x}$ \\
\hline 13.40 & $\mathrm{D}$ & 10 & 8 & 4 & rounded & $\mathrm{x}$ & $\mathrm{x}$ \\
\hline 13.50 & $\mathrm{AC}$ & 10 & 3 & 2 & rounded & $\mathrm{x}$ & $\mathrm{x}$ \\
\hline 13.60 & $\mathrm{RR}$ & 10 & 8 & 4 & rounded & $\mathrm{x}$ & $\mathrm{x}$ \\
\hline 13.65 & A & 17 & 10 & 1.5 & rounded & $\mathrm{x}$ & $\mathrm{x}$ \\
\hline 13.70 & $\mathrm{D}$ & 20 & 10 & 5 & rounded & $\mathrm{x}$ & $\mathrm{x}$ \\
\hline 13.80 & DL & 10 & 6 & 1 & rounded & & \\
\hline 13.85 & $\mathrm{RR}$ & 9 & 7 & 5 & rounded & $\mathrm{x}$ & $\mathrm{x}$ \\
\hline 13.90 & A & 16 & 6 & 3 & rounded & $\mathrm{x}$ & $\mathrm{x}$ \\
\hline 14.10 & $\mathrm{~S}$ & 6 & 6 & 3 & rounded & & $\mathrm{x}$ \\
\hline 14.15 & $\mathrm{~A}$ & 13 & 13 & 2 & rounded & $\mathrm{x}$ & $\mathrm{x}$ \\
\hline 14.25 & $\mathrm{RR}$ & 19 & 6 & 3 & rounded & $\mathrm{x}$ & $\mathrm{x}$ \\
\hline 14.30 & $\mathrm{RR}$ & 12 & 8 & 2 & rounded & $\mathrm{x}$ & $\mathrm{x}$ \\
\hline 14.45 & $\mathrm{RR}$ & 5 & 5 & 3 & rounded & $\mathrm{x}$ & $\mathrm{x}$ \\
\hline 14.50 & $\mathrm{~A}$ & 12 & 5 & 1 & rounded & $\mathrm{x}$ & $\mathrm{x}$ \\
\hline 14.55 & M & 10 & 8 & 5 & rounded & $\mathrm{x}$ & $\mathrm{x}$ \\
\hline 14.70 & A & 25 & 15 & 3 & rounded & & $\mathrm{x}$ \\
\hline 14.80 & A & 22 & 20 & 3 & rounded & $\mathrm{x}$ & $\mathrm{x}$ \\
\hline 14.90 & $\mathrm{C}$ & 15 & 7 & 7 & rounded & $\mathrm{x}$ & $\mathrm{x}$ \\
\hline 15.00 & A & 20 & 15 & 2 & rounded & & $\mathrm{x}$ \\
\hline 15.10 & $\mathrm{RR}$ & 15 & 12 & 3 & rounded & $\mathrm{x}$ & $\mathrm{x}$ \\
\hline 15.20 & PO & 8 & 5 & 3 & rounded & $\mathrm{x}$ & $\mathrm{x}$ \\
\hline 15.40 & RR & 13 & 11 & 2 & rounded & $\mathrm{x}$ & $\mathrm{x}$ \\
\hline 15.60 & $\mathrm{RR}, \mathrm{PO}$ ? & 12 & 9 & 2 & rounded & $\mathrm{x}$ & $\mathrm{x}$ \\
\hline 15.70 & A & 23 & 10 & 2 & rounded & $\mathrm{x}$ & $\mathrm{x}$ \\
\hline 15.80 & $\mathrm{C}$ & 20 & 14 & 8 & rounded & $\mathrm{x}$ & $\mathrm{x}$ \\
\hline 15.90 & A & 20 & 12 & 2 & rounded & $\mathrm{x}$ & $\mathrm{x}$ \\
\hline 16.10 & $\mathrm{RR}$ & 10 & 10 & 3 & rounded & & $\mathrm{x}$ \\
\hline$* 16.15$ & $\mathrm{~A}$ & 11 & 10 & 5 & rounded & & $\mathrm{x}$ \\
\hline$* 16.20$ & $\mathrm{C}$ & 15 & 7 & 7 & rounded & $\mathrm{x}$ & $\mathrm{x}$ \\
\hline
\end{tabular}

Table A2. Continued.

\begin{tabular}{|c|c|c|c|c|c|c|c|}
\hline $\begin{array}{r}\text { Distance } \\
\text { from } \\
\text { high } \\
\text { tide } \\
\text { line } \\
{[\mathrm{m}]}\end{array}$ & $\begin{array}{l}\text { Clast } \\
\text { type }\end{array}$ & $\begin{array}{c}\text { Size } \\
a \text { axis } \\
{[\mathrm{cm}]}\end{array}$ & $\begin{array}{c}\text { Size } \\
b \text { axis } \\
{[\mathrm{cm}]}\end{array}$ & $\begin{array}{c}\text { Size } \\
c \text { axis } \\
{[\mathrm{cm}]}\end{array}$ & Shape & $\begin{array}{l}\text { Homotrema } \\
\text { rubrum } \\
\text { encrustation }\end{array}$ & $\begin{array}{l}\text { Borings } \\
\text { on } \\
\text { surface }\end{array}$ \\
\hline$* 16.40$ & M & 7 & 6 & 5 & rounded & $\mathrm{x}$ & $\mathrm{x}$ \\
\hline$* 16.50$ & D & 18 & 15 & 5 & rounded & $\mathrm{x}$ & $\mathrm{x}$ \\
\hline 16.60 & A & 25 & 20 & 2 & rounded & $\mathrm{x}$ & $\mathrm{x}$ \\
\hline 16.65 & $S, R R$ & 10 & 6 & 2 & rounded & $\mathrm{x}$ & $\mathrm{x}$ \\
\hline 17.00 & $\mathrm{C}$ & 15 & 13 & 8 & rounded & $\mathrm{x}$ & $\mathrm{x}$ \\
\hline 17.15 & RR & 15 & 10 & 5 & rounded & $\mathrm{x}$ & $\mathrm{x}$ \\
\hline 17.20 & CA & 18 & 14 & 6 & rounded & $\mathrm{x}$ & $\mathrm{x}$ \\
\hline 17.50 & $\mathrm{D}$ & 20 & 15 & 8 & rounded & $\mathrm{x}$ & $\mathrm{x}$ \\
\hline 17.60 & A & 20 & 10 & 2 & rounded & & $\mathrm{x}$ \\
\hline 17.80 & D & 20 & 12 & 7 & rounded & $\mathrm{x}$ & $\mathrm{x}$ \\
\hline 17.90 & RR & 15 & 10 & 4 & rounded & $\mathrm{x}$ & $\mathrm{x}$ \\
\hline 18.10 & MI & 10 & 10 & 3 & rounded & $\mathrm{x}$ & $\mathrm{x}$ \\
\hline 18.20 & D & 20 & 15 & 10 & rounded & $\mathrm{x}$ & $\mathrm{x}$ \\
\hline 18.45 & RR & 15 & 8 & 7 & rounded & $\mathrm{x}$ & $\mathrm{x}$ \\
\hline 18.60 & $\mathrm{D}$ & 18 & 12 & 9 & rounded & & $\mathrm{x}$ \\
\hline 18.80 & A & 75 & 40 & 5 & karstified & & $\mathrm{x}$ \\
\hline 19.20 & RR & 15 & 10 & 3 & karstified & $\mathrm{x}$ & $\mathrm{x}$ \\
\hline 19.40 & $\mathrm{RR}$ & 15 & 10 & 5 & karstified & $\mathrm{x}$ & $\mathrm{x}$ \\
\hline 19.70 & A & 25 & 17 & 2 & rounded & & $\mathrm{x}$ \\
\hline 19.80 & $\mathrm{~S}$ & 45 & 20 & 9 & rounded & $\mathrm{x}$ & $\mathrm{x}$ \\
\hline 20.20 & A & 18 & 13 & 3 & rounded & $\mathrm{x}$ & $\mathrm{x}$ \\
\hline 20.60 & RR & 35 & 20 & 12 & karstified & $\mathrm{x}$ & $\mathrm{x}$ \\
\hline 20.80 & M & 20 & 15 & 10 & rounded & & $\mathrm{x}$ \\
\hline 21.10 & $\mathrm{RR}$ & 25 & 13 & 2 & karstified & $\mathrm{x}$ & $\mathrm{x}$ \\
\hline 21.20 & M & 25 & 15 & 10 & rounded & $\mathrm{x}$ & $\mathrm{x}$ \\
\hline 21.60 & MC & 28 & 10 & 8 & rounded & $\mathrm{x}$ & $\mathrm{x}$ \\
\hline 22.00 & RR & 20 & 13 & 3 & karstified & $\mathrm{x}$ & $\mathrm{x}$ \\
\hline 22.10 & PO & 23 & 20 & 8 & rounded & $\mathrm{x}$ & $\mathrm{x}$ \\
\hline 22.60 & A & 30 & 25 & 2 & rounded & & $\mathrm{x}$ \\
\hline 23.20 & BR & 25 & 18 & 7 & rounded & & $\mathrm{x}$ \\
\hline 23.50 & $\mathrm{D}$ & 28 & 18 & 9 & rounded & $\mathrm{x}$ & $\mathrm{x}$ \\
\hline
\end{tabular}

$\mathrm{A}=$ Acropora $; \mathrm{AC}=$ Acropora cernivoris $; \mathrm{AP}=$ Acropora palmata $; \mathrm{BR}=$ beach rock $\mathrm{C}=$ conch $\mathrm{CA}=$ coralline algac $\mathrm{D}=$ Diploria $; \mathrm{DL}=$ Diploria labyrinthiformis; $\mathrm{M}=$ Montastrea $; \mathrm{MC}=$ Montastrea cavernosa $; \mathrm{MI}=$ Milleporida; $\mathrm{RR}=$ reef rock; $\mathrm{PA}=$ Pleistocene limestone; $\mathrm{PO}=$ Porites $; \mathrm{S}=$ serpuilte rock.

Acknowledgements. This work was carried out as part of the US Geological Survey's "Tsunami Hazards Potential in the Caribbean" project. The Department of Disaster Management of the government of the British Virgin Islands provided high-resolution aerial images and helped to organize the field trip. U. ten Brink and Y. Wei conducted the DGPS-surveys. M. Tuttle and U. ten Brink provided helpful information (including photographs) on coastal changes close to Windlass Bight after hurricane Earl. Z. Fuentes gave a comprehensive overview of sediments possibly related to the 1755 tsunami. B. Atwater was available for questions of any kind and carefully reviewed a first version of the manuscript. The submission benefitted from constructive review comments by B. Jaffe and R. Paris. We acknowledge the financial publication support by the Deutsche Forschungsgemeinschaft (DFG) and the Open Access Publishing Fund of the Westfälische-Wilhelms Universität Münster.

Edited by: J. Roger

Reviewed by: B. Jaffe and R. Paris

\section{References}

Anthony, E. J.: Beach-ridge development and sediment supply: examples from West Africa, Mar. Geol., 129, 175-186, 1995.

Atwater, B. F., ten Brink, U. S., Feuillet, N., Fuentes Figueroa, Z., Halley, R. B., Tuttle, M. P., Wei, Y., and Weil Accardo, J.: Geologic evidence for a medieval tsunami with an eastern source 
along the Puerto Rico Trench, AGU Fall Meeting, San Francisco, USA, 3-7 December 2012, T41A-2566, 2012a.

Atwater, B. F., ten Brink, U. S., Buckley, M., Halley, R. B., Jaffe, B. E., López-Venegas, A. M., Reinhardt, E. G., Tuttle, M. P., Watt, S., and Wei, Y.: Geomorphic and stratigraphic evidence for an unusual tsunami or storm a few centuries ago at Anegada, British Virgin Islands, Nat. Hazards, 63, 51-84, 2012 b.

Atwater, B. F., ten Brink, U. S., Fuentes, Z., Halley, R. B., Spiske, M., Tuttle, M. P., and Wei, Y.: Further evidence for a medieval tsunami from the Puerto Rico Trench, AGU Fall Meeting, San Francisco, USA, 9-13 December 2013, NH31A-1591, 2013.

Atwater, B. F., Fuentes, Z., Halley, R. B., ten Brink, U. S., and Tuttle, M. P.: Effects of 2010 Hurricane Earl amidst geologic evidence for greater overwash at Anegada, British Virgin Islands, Adv. Geosci., in press, 2014.

Baines, G. B. K. and McLean, R. F.: Sequential studies of hurricane deposit evolution at Funafuti atoll, Mar. Geol., 21, M1-M8, 1976.

Baines, G. B. K., Beveridge, P. J., and Maragos, J. E.: Storms and island building at Funafuti Atoll, Ellice Islands, in: Proceedings 2nd International Coral Reef Symposium, Brisbane, Australia, 2, 485-496, 1974.

Barkan, R., ten Brink, U. S., and Lin, J.: Far field tsunami simulations of the 1755 Lisbon earthquake: Implications for tsunami hazard to the U.S. East Coast and the Caribbean, Mar. Geol., 264, 109-122, 2009.

Bishop, P. and Hughes, M.: Imbricate and fitted fabrics in coastal boulder deposits on the Australian east coast, Geology, 17, 544547, 1989.

Bluck, B. J.: Sedimentation of beach gravels; examples from South Wales, J. Sediment. Petrol., 37, 128-156, 1967.

Blumenstock, D. I., Johnson, C. G., and Fosberg, F. R.: Re-survey of typhoon effects on Jaluit Atoll in Marshall Islands, Nature, 189, 618-620, 1961.

Buckley, M., Wei, Y., Jaffe, B., and Watt, S.: Inverse modeling of velocities and inferred cause of overwash that emplaced inland fields of boulders at Anegada, British Virgin Islands, Nat. Hazards, 63, 133-149, 2012.

Cangialosi, J. P.: Tropical cyclone report Hurricane Earl (AL072010) 25 August-4 September 2010: National Hurricane Center, available at: http://www.nhc.noaa.gov/pdf/ TCR-AL072010_Earl.pdf, 29 pp., last access: July 2013, 2011.

Caron, V.: Contrasted textural and taphonomic properties of highenergy wave deposits cemented in beachrocks (St. Bartholomew Island, FrenchWest Indies), Sediment. Geol., 237, 189-208, 2011.

Claudino-Sales, V., Wang, P., and Horwitz, M. H.: Factors controlling the survival of coastal dunes during multiple hurricane impacts in 2004 and 2005: Santa Rosa Barrier Island, Florida, Geomorphology, 95, 295-315, 2008.

Dunn, G. E.: The hurricane season of 1960, Mon. Weather Rev., 89, 99-108, 1961.

Dunne, R. P. and Brown, B. E.: Some aspects of the ecology of reefs surrounding Anegada, British Virgin Islands, Atoll Research Bulletin, 236, 1-83, 1979.

Etienne, S. and Paris, R.: Boulder accumulations related to storms on the south coast of the Reykjanes Peninsula (Iceland), Geomorphology, 114, 55-70, 2010.
Etienne, S., Buckley, M., Paris, R., Nandasena, A. K., Clark, K., Strotz, L., Chagué-Goff, C., Goff, J., and Richmond, B.: The use of boulders for characterising past tsunamis - Lessons from the 2004 Indian Ocean and 2009 South Pacific tsunamis, Earth-Sci. Rev., 107, 76-90, 2011.

Forsyth, A. J., Nott, J., and Bateman, M. D.: Beach ridge plain evidence of a variable late-Holocene tropical cyclone climate, North Queensland, Australia, Palaeogeogr. Palaeocl., 297, 707716, 2010.

Gardner, T. A., Cote, I. M., Gill, J. A., Grant, A., and Watkinson, A. R.: Long-term region-wide declines in Caribbean corals, Science, 301, 958-960, 2003.

Goff, J., McFadgen, B. G., and Chagué-Goff, C.: Sedimentary differences between the 2002 Easter storm and the 15th-century Okoropunga tsunami, southeastern North Island, New Zealand, Mar. Geol., 204, 235-250, 2004.

Goto, K., Sugawara, D., Ikema, S., and Miyagi, T.: Sedimentary processes associated with sand and boulder deposits formed by the 2011 Tohoku-oki tsunami at Sabusawa Island, Japan, Sediment. Geol., 282, 188-198, 2012.

Harms, J. C., Southard, J. B., Spearing, D. R., and Walker, R. G.: Depositional environments as interpreted from primary sedimentary structures and stratification sequences, Society of Economic Paleontologists and Mineralogists, Short Course no. 2, 161 pp., 1975.

Harvey, N.: Holocene coastal evolution: Barriers, beach ridges, and tidal flats of South Australia, J. Coastal Res., 22, 90-99, 2006.

Howard, J.: Reconnaissance geology of Anegada Island, Caribbean Research Institute, St. Thomas, 1970.

IRF: An environmental profile of the island of Anegada, British Virgin Islands, in: The British Virgin Islands environmental profile series, 3, 306 pp., available at: http://www.irf.org/documents/BVI/BVI\%20Environmental\% 20Profile/Anegada\%20Environmental\%20Profile-FINAL.pdf (last access: October 2013), 2013.

Johansson, C. E.: Structural studies of frictional sediments, Geogr. Ann. A, 58, 201-301, 1976.

Lorang, M. S.: Predicting threshold entrainment mass for a boulder beach, J. Coastal Res., 16, 432-445, 2000.

MacKenzie, F. T., Kulm, L. D., Cooley, R. L., and Barnhart, J. T.: Homotrema Rubrum (Lamarck), a sediment transport indicator, J. Sediment. Res., 35, 265-272, 1965.

Maragos, J. E., Baines, G. B. K., and Beveridge, P. J.: Tropical cyclone creates a new land formation on Funafuti Atoll, Science, 181, 1161-1164, 1973.

May, S. M., Engel, M., Brill, D., Squire, P., Scheffers, A., and Kelletat, D.: Coastal hazards from tropical cyclones and extratropical winter storms based on Holocene storm chronologies, in: Coastal Hazards, Springer Netherlands, Chapter 20, 557-585, 2013.

McCann, W., Feldman, L., and McCann, M.: Catalog of felt earthquakes for Puerto Rico and neighboring islands 1492-1899 with additional information for some 20th century earthquakes, material provided as a pdf file by WR McCann, 122 pp., unpublished.

McKee, E. D.: Storm sediments on a Pacific atoll, J. Sediment. Petrol., 29, 354-364, 1959.

Meteo365: Seasonal Loblolly Bay Swell and Wind Distribution, available at: http://www.surf-forecast.com/breaks/Soldier-Point/ reliability_by_season, last access: October 2012, 2013. 
Miller, J., Muller, E., Rogers, C., Waara, R., Atkinson, A., Whelan, K. R. T., Patterson, M., and Witcher, B.: Coral disease following massive bleaching in 2005 causes $60 \%$ decline in coral cover on reefs in the US Virgin Islands, Coral Reefs, 28, 925-937, 2009.

Morton, R. A., Richmond, B. M., Jaffe, B. E., and Gelfenbaum, G.: Reconnaissance investigation of Caribbean extreme wave deposits - Preliminary observations, interpretations, and research directions, U.S. Geological Survey Open-File Report 2006-1293, available at: http://pubs.usgs.gov/of/2006/1293/ of2006-1293.pdf, last access: October 2013, 46 pp., 2006.

Morton, R. A., Richmond, B. M, Jaffe, B. E., and Gelfenbaum, G.: Coarse-clast ridge complexes of the Caribbean - a preliminary basis for distinguishing tsunami and storm-wave origins, J. Sediment. Res., 78, 624-637, 2008.

National Oceanic and Atmospheric Administration: Historical hurricane tracks, available at: http://www.csc.noaa.gov/ hurricanes/\#, last access: July 2013, 2012.

Nott, J.: Palaeotempestology: the study of prehistoric tropical cyclones - a review and implications for hazard assessment, Environ. Int., 30, 433-447, 2004.

Oak, H .L.: The boulder beach: a fundamentally distinct sedimentary assemblage, Ann. Assoc. Am. Geogr., 74, 71-82, 1984.

Ogren, D.E. and Waag, C.J.: Orientation of cobble and boulder beach clasts, Sediment. Geol., 47, 69-76, 1986.

Ortlieb, L., Fournier, M., and Machare, J.: Sequences of Holocene beach ridges in northern Peru - chronological framework and possible relationships with former El Niño events, Paleo ENSO Records International Symposium, Lima March 1992, Extended abstracts, ORSTOM-CONCYTEC, 215-223, 1992.

Otvos, E. G.: Beach ridges - definitions and significance, Geomorphology, 32, 83-108, 2000.

Pickering, V. W.: Early history of the British Virgin Islands: from Columbus to emancipation, Falcon Publications International, UK, 248 pp., 1983.

Paris, R., Cachao, M., Fournier, J., and Voldoire, O.: Nannoliths abundance and distribution in tsunami deposits: example from the December 26, 2004 tsunami Lhok Nga (northwest Sumatra, Indonesia), Géomorphologie: Relief, Processus, Environnement, 1, 109-118, 2010.

Paris, R., Naylor, L. A., and Stephenson, W. J.: Boulders as a signature of storms on rock coasts Preface, Mar. Geol., 283, 1-11, 2011.

Pilarczyk, J. and Reinhardt, E.: Homotrema rubrum (Lamarck) taphonomy as an overwash indicator in Marine Ponds on Anegada, British Virgin Islands, Nat. Hazards, 63, 85-100, 2012.

Pohl, W. and Schneider, J.: Impact of endolithic biofilms on carbonate rock surfaces, Geological Society of London, Special Publications, 205, 177-194, 2002.

Reinhardt, E., Pilarczyk, J., and Brown, A.: Probable tsunami origin for a shell and sand sheet from marine ponds on Anegada, British Virgin Islands, Nat. Hazards, 63, 101-117, 2012.

Richmond, B. and Morton, R.: Coral-Gravel Storm Ridges: Examples from the Tropical Pacific and Caribbean, Coastal Sediments '07, 572-583, doi:10.1061/40926(239)43, 2007.

Richmond, B. M., Watt, S., Buckley, M., Jaffe, B. E., Gelfenbaum, G., and Morton, R. A.: Recent storm and tsunami coarse-clast deposit characteristics, southeast Hawaii, Mar. Geol., 283, 7989, 2011.
Scheffers, A., Engel, M., Scheffers, S., Squire, P., and Kelletat, D.: Beach ridge systems - archives for Holocene coastal events?, Prog. Phys. Geog., 36, 5-37, 2011.

Scheffers, A. M., Scheffers, S. R., Kelletat, D. H., Squire, P., Collins, L., Feng, Y., Zhao, J.-X., Joannes-Boyau, R., May, S. M., Schellmann, G., and Freeman, H.: Coarse clast ridge sequences as suitable archives for past storm events? Case study on the Houtman Abrolhos, Western Australia, J. Quaternary Sci., 27, 713-724, 2012.

Schomburgk, R. H.: Remarks on Anegada, Journal of the Royal Geographical Society of London, 2, 152-170, 1832.

Scoffin, T. P.: The geological effects of hurricanes on coral reefs and the interpretation of storm deposits, Coral Reefs, 12, 203221, 1993.

Spiske, M. and Jaffe, B. E.: Sedimentology and hydrodynamic implications of a coarse-grained hurricane sequence in a carbonate reef setting, Geology, 37, 839-842, 2009.

Spiske, M., Böröcz, Z., and Bahlburg, H.: The role of porosity in discriminating between tsunami and hurricane emplacement of boulders - a case study from the Lesser Antilles, southern Caribbean, Earth Planet. Sc. Lett., 268, 384-396, 2008.

Sugawara, D., Minoura, K., and Imamura, F.: Tsunamis and tsunami sedimentology, in: Tsunamiites, edited by: Shiki, T., Tsuji, Y., Yamazaki, T., and Minoura, K., Elsevier, Amsterdam, 9-51, 2008.

Tamura, T.: Beach ridges and prograded beach deposits as palaeoenvironment records, Earth-Sci. Rev., 114, 279-297, 2012.

Tanner, W. F.: Origin of beach ridges and swales, Mar. Geol., 129, 149-161, 1995.

Taylor, M. and Stone, G. W.: Beach ridges - a review, J. Coastal Res., 12, 612-621, 1996.

Watt, S., Buckley, M., and Jaffe, B.: Inland fields of dispersed cobbles and boulders as evidence for a tsunami on Anegada, British Virgin Islands, Nat. Hazards, 63, 119-131, 2012.

Wei, Y., ten Brink, U., Atwater, B. F., Tuttle, M. P., Halley, R., Feuillet, N., Weil Accardo, J., and Fuentes, Z.: Near-field tsunami inferred from numerical modeling of medieval overwash at Anegada, British Virgin Islands, AGU Fall Meeting, San Francisco, USA, 3-7 December 2012, OS32A-05, 2012.

Weil Accardo, J., Feuillet, N., Halley, R. B., Atwater, B. F., Ten Brink, U. S., Deschamps, P., Tuttle, M. P., Wei, Y., and Fuentes Figueroa, Z.: Age of overwash and rate of relative sea-level rise inferred from detrital heads and microatolls of medieval corals at Anegada, British Virgin Islands, AGU Fall Meeting, San Francisco, USA, 3-7 December 2012, T41A-2562, 2012.

Weiss, R.: The mystery of boulders moved by tsunamis and storms, Mar. Geol., 295-298, 28-33, 2012.

Wells, L. E.: The Santa beach ridge complex: sea-level and progradational history of an open gravel coast in Central Peru, J. Coastal Res., 12, 1-17, 1996.

Williams, D. M. and Hall, A. M.: Cliff-top megaclast deposits of Ireland, a record of extreme waves in the North Atlantic - storms or tsunamis?, Mar. Geol., 206, 101-117, 2004. 